\title{
Effect of Helminth Infestationin Children Infected with Human Immunodeficiency Virus (HIV)
}

\author{
Maria Lauretta Orji ${ }^{1}$, Nnamdi Benson Onyire ${ }^{2}$, Bede C Ibe3, Roland Ibekwe ${ }^{4}$
}

\begin{abstract}
Introduction: Infection by human immunodeficiency virus results in immune destruction, while studies among the Ethiopian immigrants in Israel showed that chronic helminthiasis induces immune dysregulation. With destruction of CD4+ cell and consequently progression to AIDS, the host may be more susceptible to invading organisms such as helminths. This study was aimed at determining the effect of immune state on the prevalence and intensity of helminth infection in HIV infected children in two hospitals in Abakaliki. Material and Methods: It was a cross sectional study that involved consecutive recruitment of 84 confirmed HIV infected children attending the ART clinic. Stool analysis for subjects was done, using the Kato-Katz technique. Blood sample for estimation of CD4 cell count was carried outusing flow cytometer from the HIV positive subjects. Results: A total of 84 subjects were recruited during the study period, majority were males $(58.3 \%)$. Male to female ratio was $1.4: 1$. The age range of participants was 2-17 years, while mean age of subjects infected with helminthiasis was $6.10 \pm 3.34$ year. A significant number of subjects in advanced and severe immunological stages had helminthiasis $\left(X^{2}=12.49, p=0.001\right)$. There was however no significant relationship between intensity of helminthiasis and immunologic stages of subjects. Conclusion: The study suggests that immunodeficiency state may increase the susceptibility of helminth infection in HIV infected children. Hence children with HIVIAIDS may benefit from routine testing and/or de-worming of helminth infection.
\end{abstract}

Key words: Helminthiasis, HIVIAIDS, Immunodeficiency,

\section{Introduction}

$\mathrm{B}^{\mathrm{s}}$ the end of 2015, the total number of people living with HIV worldwide was about 36.7 million of this total number, about 1.8 million were children aged $0-14$ years and 6.5 million of global total were in the western and central Africa ${ }^{1}$. Nigeria has the second largest HIV burden in the world, with approximately 3.5 million people living with HIV. The prevalence of HIV in Nigeria is $3.4 \%$ while the prevalence of HIV in Ebonyi state is $0.9 \% \%^{2,3,5}$. As HIV infection progresses to acquired immune deficiency syndrome (AIDS), there is consequent
${ }^{1}$ Dr. Maria Lauretta Orji, Department of Paediatrics, Federal Teaching Hospital Abakaliki (FETHA), Ebonyi State, ${ }^{2} \mathrm{Dr}$. Nnamdi Benson Onyire, Department of Paediatrics, Federal Teaching Hospital Abakaliki (FETHA), Ebonyi State, Nigeria, ${ }^{3}$ Dr. Bede C Ibe, Department of Paediatrics, University of Nigeria Teaching Hospital, Ituku-Ozalla, Enugu State, Nigeria, ${ }^{4}$ Dr. Roland Ibekwe, Department of Paediatrics, University of Nigeria Teaching Hospital, Ituku-Ozalla, Enugu State, Nigeria.

\author{
Address for correspondence \\ Maria Lauretta Orji, \\ Department of Paediatrics, \\ Federal Teaching Hospital Abakaliki (FETHA), \\ Ebonyi State, Nigeria \\ Tel No; +2347034565992 \\ E-mail: drlauretta2002@gmail.com
}

\section{Acknowledgements: None \\ Funding: Nil \\ Conflict of Interest: None \\ Permission from IRB: Yes}

\section{How to cite}

Maria Lauretta Orji, Nnamdi Benson Onyire, Bede C Ibe, Roland Ibekwe. Effect of Helminth Infestationin Children Infected with Human Immunodeficiency Virus (HIV). J Nepal Paediatr Soc 2017;37(1):25-30.

doi: http://dx.doi.org/10.3126/jnps.v37i1.16474

This work is licensed under a Creative Commons Attribution 3.0 License. 
destruction of the CD4+ cells $\mathrm{s}^{4,5}$. Immunodeficiency state reduces the host ability to fight invading organisms ${ }^{6}$. These organisms can be micro-cellular (virus, bacterial and fungal) ormacro-cellular (helminths) ${ }^{7}$. Many helminth parasites are long-lived and cause chronic infections ${ }^{8,9}$. Chronic helminth infestation was reported to cause immune dysregulations, characterized by a dominant Th2 type of cytokine immune response (predominantly IL-4 and IL-5, IL-10), a high IgE levels, eosinophilia, low CD4+ and a high CD8+ cells count ${ }^{10,11,12}$.

Study by Assefaet $a /^{13}$ looked at the prevalence of intestinal parasitic infections in relation to HIVIAIDS status, diarrhea and CD4 T-cell count among 214 HIV infected adults and 164 HIV negative controls. They reported a significantly higher prevalence rate of helminthiasis in HIV infected subjects (59.8\%) compared to controls $(48.8 \%)$. They also observed that the rate of parasitic infestation was increased with decreasing CD4 T-cell count among HIV infected subjects. The highest infection rate was at CD4 count of less than $200 \mathrm{cells} / \mu \mathrm{L}$ and it was about six-fold higher compared with individuals having counts of greater than 500 cells/ $\mu \mathrm{L}$. Akinboet $\mathrm{a} \mathrm{I}^{14}$ in a cross sectional study of $2000 \mathrm{HIV}$ positive adult patients and 500 control subjects in a tertiary health facility in Nigeria, reported a prevalence rate of $15.3 \%$ in HIV positive patients while $6.2 \%$ was noted among HIV negative controls. They observed a significantly higher prevalence rate of helminthiasis with decreasing CD4 T-cell count.

Epidemiological studies, mainly in adults, reported higher prevalence rates of helminth infestations in HIV infected patient compared to controls ${ }^{14,15,16}$. Hailmariam et a/15 conducted a study among HIV infected adult in Ethiopian and reported a higher prevalence rate of helminthiasis with decreasing CD4 T-cell count, similar to that reported by Akinbo et $a{ }^{16}$ in Nigeria. Generally, there is paucity of published data on intestinal helminthiasis in HIV infected children in Nigeria. Wagbatsoma et a/ ${ }^{17}$ carried out a cross sectional study on HIV seropositivity and intestinal helminthiasis among children in a tertiary health facility in Benin city, Nigeria. They reported a significantly higher prevalence rate of helminth infection $(21.4 \%)$ in HIV infected children compared to controls (9.6\%). Wagbatsoma et $a l^{17}$ however did not consider the possible effect of immune state on the prevalence of helminth infection in the study, hence the need for this study

\section{Material and Methods}

It was a cross sectional hospital based study carried out in two health facilities - Federal Teaching Hospital Abakaliki (FETHA) and Mile Four Maternity and Children Hospital, both located in Abakaliki, the Ebonyi State capital, from July 2013 to October 2013. It involved consecutive recruitment of 84 confirmed HIV infected children attending the ART clinic.

Ebonyi State is located in the rain forest zone, the climate is tropical. The annual rainfall varies from $2,000 \mathrm{~mm}$ in the Southern areas to $1,150 \mathrm{~mm}$ in the north ${ }^{18}$. The temperature throughout the year ranges between $21^{\circ} \mathrm{C}$ to $30^{\circ} \mathrm{C}^{18}$. It has two seasons, dry and wet. The dry season lasts from November to March while the rainy season lasts from April to October ${ }^{18}$. It has a total population of 2,173,501 people, majority of which are $\operatorname{lgbos}^{19}$.

The Federal Teaching Hospital Abakaliki (FETHA) operates a provider-initiated HIV testing and counseling (PITC), in which every child that presents at the Children Out-patient Clinic is offered HIV antibody test irrespective of presenting complaint, except on objection by the caregiver, however objection (opt-out) of the caregiver to the screening test does not affect quality of treatment given to the child. Any child who tested positive to the test is referred to the ART Clinic for further evaluation and management. The Children Out-patient Clinic runs on daily basis with an average patient attendance of 35 patients per clinic day. Mile Four Maternity and Children Hospital was established in 1946. It is a mission hospital

Sample size was calculated using the prevalence rate reported by Wagbatsoma et a ${ }^{17}(21.4 \%)$. A minimum sample size of 84 was obtained.

Inclusion criteria were; Children aged 2-17 years that are confirmed HIV positive and Selected children whose parents/guardian gave informed consent similarly the Exclusion criteria were; Age less than 2 years or more than 17 years and children who had received anti-helminthic drugs in the past (within 3 months) and also those children whose parents did not give informed written consent.

Approval from the Health Research and Ethical Committee of FETHA was obtained and permission from the authorities of Mile Four Maternity and Children's Hospital was also obtained before the commencement of study. The study was explained to parents/guardian and only those who gave informed consent were included in the study.

The subjects that have been regular to ART clinics (FETHA and Mile Four Hospital) in the past one year prior to the study and newly diagnosed HIV infected children that were referred from the Children Outpatient Clinic within the study period were recruited consecutively until sample size was met, a structured 
questionnaire was used to obtain information. Only one stool sample was required from each subject. The stool sample was analyzed using WHO recommended method for stool analysis for helminths -the Kato-Katz technique in the hospital laboratory of FETHA ${ }^{20}$. The stool slide is prepared following guideline from the Kato-Katz manual, starting at a corner of the slide the preparation was systematically examined under a light microscope, using $\times 40$ lens moving it back and forth across and noting the number of eggs found and the species of helminth. The number counted was multiplied by a factor of 24 , to obtain the number of eggs per gram of faeces (epg) as recommended by $\mathrm{WHO}^{20}$. The epg gave an estimation of the worm burden (intensity). ${ }^{20}$

Three milliliters of blood was collected in EDTA bottles, by the laboratory scientist in the hospital laboratory, with universal precautions ensured. The CD4+ percentages (for children less than 5 years) and CD4+ T-lymphocyte count (for children five years and above) were done in the hospital laboratory of FETHA using a flow cytometer (Cyflow SL, Partec, Munster, Germany) a modification of a commercially available 4-parameter flow cytometer, Luminex 100 (Luminex, Austin Texas, USA). Immunological classification of subjects was done based on age related CD4+ $\mathrm{T}$ lymphocyte count and percentages ${ }^{4}$. Based on this, subjects were classified as not significant, mild, advanced or severe as shown in Table 1 below.

The data obtained was entered into spread sheet using the Microsoft excel 2007 and the analysis was done using the Statistical Package for Social Science version 19.0. Descriptive results were expressed as frequencies and percentages. The significance of associations between categorical variables was tested using Pearson's chi-square and Fischer's exact tests for comparison of proportions. The level of statistical significance was achieved if $p<0.05$

\section{Results}

A total of 84 subjects were recruited during the study period, out of which $86.9 \%$ were on ART. Majority were males $49(58.3 \%)$. Male to female ratio was 1.4:1. The age range of participants was 2-17 years. The mean age of subjects infected with helminthiasis was $6.10 \pm 3.34$ year. A total of $24(28.6 \%)$ of subjects were infected with helminth. Children between 6 years and 12 years had the highest prevalence rate of infection, while males had more helminthiasis than females. There was however no significant relationship between age, gender and prevalence of helminth infection as shown in Table 2 below.

Distribution of helminthiasis to the different immunological stages: Of the 84 subjects that participated in the study, $24(28.6 \%)$ had helminthiasis. Majority of the subjects $(61.9 \%)$ were in not significant stage of immunodeficiency as shown in Table 3. Subjects in 'not significant immunodeficiency' stage of HIV infection had the least prevalence rate of helminthiasis (15.4\%) while those in 'advanced immunodeficiency' stage had the highest prevalence rate $(80.0 \%)$ as shown in Table 3

The relationship between intensity of helminth infection and immunologic classification is shown in Table 4 below. The intensity of infection was light $(<1,000 \mathrm{epg})$ for all species of intestinal helminths in subjects according to grading of helminths by WHO. ${ }^{20}$ Table 4 shows that there was no significant relationship between immunologic classification and intensity of helminth $(p=0.303)$

Socio-demographic variables versus helminth infections: Children without toilet facility had the highest prevalence rate of helminth infection $(54.2 \%)$, Lower social class, no hand washing after defaecation and lack of foot wear were factors that influenced prevalence rate of helminth infection as shown in Table 5 below

The species of helminth isolated were Hookworm (12/24, 50.0\%), A. lumbricoides (9/24, 37.5\%), $T$. trichiura $(2 / 24,8.3 \%)$, and S.stercoralis $(1 / 24,4.2 \%)$ as shown in Table 6 . Only one species of helminth was isolated from infected subjects, there were no mixed infections.

Table 1: Proposed WHO (2006) classification of HIV-associated immunodeficiency in infants and children. ${ }^{4}$

\begin{tabular}{|c|c|c|c|c|}
\hline \multirow{3}{*}{ Immunologic category } & \multicolumn{4}{|c|}{ Age-related CD4 T lymphocyte values (Percentage (\%) of normal) } \\
\hline & $<11$ months & 12-35 months & 36-59 months & $\geq 5 y e a r s$ \\
\hline & $(\%)$ & $(\%)$ & $(\%)$ & Cells $/ \mathrm{mm}^{3}$ \\
\hline Not significant & $>35$ & $>30$ & $>25$ & $>500$ \\
\hline Mild & $30-35$ & $25-30$ & $20-25$ & $350-499$ \\
\hline Advanced & $25-30$ & $20-25$ & $15-20$ & $200-349$ \\
\hline Severe & $<25$ & $<20$ & $<15$ & $<200$ or $<15 \%$ \\
\hline
\end{tabular}


Table 2: Age and Sex-related distribution of soil-transmitted helminths in HIV infected children

\begin{tabular}{lcccc}
\hline Age (years) & No. tested & No. infected with helminth (\%) & $\mathbf{X}^{2}$ & $p=$ value \\
\hline$\leq 5$ & 35 & $10(28.6)$ & - & - \\
\hline $6-12$ & 38 & $11(28.9)$ & 0.72 & 0.696 \\
\hline$>12$ & 11 & $3(27.3)$ & - & - \\
\hline Total & $\mathbf{8 4}$ & $\mathbf{2 4 ( 2 8 . 6 )}$ & - & - \\
\hline Sex & & & - & - \\
\hline Male & 49 & $15(30.6)$ & 0.12 & 0.599 \\
\hline Female & 35 & $9(25.7)$ & - & - \\
\hline Total & $\mathbf{8 4}$ & $\mathbf{2 4 ( 2 8 . 6 )}$ & & - \\
\hline
\end{tabular}

Table 3: Distribution of helminth infection to the different immunologic stages

\begin{tabular}{lcc}
\hline Immunologic classification (Using CD4 T-cell count/\%) & Number tested (\%) & Infected subjects (\%) \\
\hline Not significant & $52(61.9)$ & $8(15.4)$ \\
\hline Mild & $18(21.4)$ & $5(27.7)$ \\
\hline Advanced & $10(11.9)$ & $8(80.0)$ \\
\hline Severe & $4(4.8)$ & $3(75.0)$ \\
\hline Total & $\mathbf{8 4 ( 1 0 0 . 0 )}$ & $\mathbf{2 4}(\mathbf{2 8 . 6 )}$ \\
\hline
\end{tabular}

$\mathrm{X}^{2}=12.49, p=0.001$

Table 4: Relationship between intensity of helminth infection and immunologic classification

\begin{tabular}{|c|c|c|c|c|}
\hline \multirow{2}{*}{$\begin{array}{l}\text { Immunologic classification } \\
\text { (Using CD4 T-cell count/\%) }\end{array}$} & \multicolumn{3}{|c|}{$\begin{array}{l}\text { Intensity of helminth infection estimated by egg per gram } \\
\text { of stool (epg) }\end{array}$} & \\
\hline & $<240$ epg & $240-480$ epg & $>480$ epg & \\
\hline Not significant & 1 & 4 & 3 & $x^{2}=78.9$ \\
\hline Mild & 2 & 1 & 2 & $P=0.303$ \\
\hline Advanced & 2 & 5 & 1 & \\
\hline Severe & 0 & 2 & 1 & \\
\hline
\end{tabular}

Table 5: Effect of some socio-demographic variables on the prevalence ofintestinal helminthiasis in subjects

\begin{tabular}{|c|c|c|c|c|}
\hline \multirow{2}{*}{ Variables } & \multicolumn{2}{|c|}{ HIV infected Subjects } & \multirow{2}{*}{$x^{2}$} & \multirow{2}{*}{$p$-value } \\
\hline & No. tested $(n=84)$ & No. infected with helminth (\%) & & \\
\hline \multicolumn{5}{|c|}{ Presence/Type of toilet } \\
\hline Water cistern & 34 & $2(5.9)$ & & \\
\hline Pit latrine & 26 & $9(34.6)$ & 12.77 & 0.002 \\
\hline No toilet facility & 24 & $13(54.2)$ & & \\
\hline \multicolumn{5}{|c|}{ Source of drinking water } \\
\hline Tap & 20 & $2(10.0)$ & & \\
\hline Borehole/Well & 36 & $16(44.4)$ & 4.95 & 0.420 \\
\hline Others & 28 & $6(21.4)$ & & \\
\hline \multicolumn{5}{|l|}{ Social class } \\
\hline Upper & 43 & $7(16.3)$ & 6.42 & 0.028 \\
\hline Lower & 41 & $17(41.5)$ & & \\
\hline \multicolumn{5}{|l|}{ Hand washing } \\
\hline Yes & 66 & $12(18.2)$ & 12.77 & 0.002 \\
\hline No & 18 & $12(66.7)$ & & \\
\hline \multicolumn{5}{|c|}{ Use of foot wear(n=73) } \\
\hline Yes & 63 & $12(19.0)$ & 36.07 & 0.000 \\
\hline No & 10 & $9(90.0)$ & & \\
\hline
\end{tabular}


Table 6: Species prevalence rates of intestinal helminths among subjects in different immunodeficiency stages

\begin{tabular}{lccccc}
\hline \multirow{2}{*}{ Organism } & \multicolumn{5}{c}{ Classification of HIV associated immunodeficiency } \\
\cline { 2 - 6 } & Not significant (\%) & $\begin{array}{c}\text { Mild } \\
(\%)\end{array}$ & Advanced (\%) & $\begin{array}{c}\text { Severe } \\
(\%)\end{array}$ & $\begin{array}{c}\text { Total } \\
(\%)\end{array}$ \\
\hline Hookworm & $7(29.2)$ & $2(8.3)$ & $3(12.5)$ & $0(0.0)$ & $12(50.0)$ \\
\hline A.Lumbricoides & $0(0.0)$ & $1(4.2)$ & $5(20.8)$ & $3(12.5)$ & $9(37.5)$ \\
\hline T.Trichiura & $1(4.2)$ & $1(4.2)$ & $0(0.0)$ & $0(0.0)$ & $2(8.3)$ \\
\hline S.stercoralis & $0(0.0)$ & $1(4.2)$ & $0(0.0)$ & $0(0.0)$ & $1(4.2)$ \\
\hline & $\mathrm{X}^{2}=17.667$ & & $p=0.039$ & & \\
\hline
\end{tabular}

\section{Discussion}

Chronic inflammation from helminth infection results in immune dysregulation and reduction in CD4 T-cell count ${ }^{10,11,12}$. This was corroborated in index study where prevalence rates of helminth infection were highest in subjects with advanced and severe immunodeficiency stages of the disease. This suggests that there may be an increased morbidity and mortality in HIV/helminth coinfection since helminth infection alone lowers the CD4 T-cell count in affected host Low socio-economic class and lack of toilet facilities, poor hand washing practices, lack of foot wear use were significant risk factors to the acquisition of helminth infestation in this study. These socio-demographic variables are common underlying factors influencing prevalence rate of helminth infection in resource poor countries like Nigeria ${ }^{21-22}$.

Observation from this study showed that subjects in advanced and severe immunodeficiency stages had higher prevalence rates of helminthiasis compared to those in mild and not significant immunodeficiency stages. This agreed with findings by Assefa et a/ ${ }^{13}$ and Akinbo et a/14. The exact mechanism by which immunodeficiency facilitates parasitic infection is not clear, although immune deficient patients are at risk of many diseases, which can be helminth infection.

Although hookworm infection was predominant in index study, subjects with $A$. lumbricoides had the highest prevalence rates of advanced and severe stages of AIDS. This suggests that predominance of A. lumbricoides in a host, may elicit chronic immune activation that may depress immune system. This finding was corroborated by Assefa et $a l^{13}$ and Akinbo et al ${ }^{14}$ that reported a predominance of $A$. lumbricoides among subjects with advanced and severe immunodeficiency stages of HIV. Similarly study by Mkhize-kwitshana et $a^{23}$ reported that HIV infected subjects with high viral loads are at higher risk of $A$. lumbricoides infection when compared to subjects with lower viral load. This may suggests that $A$. lumbricoides elicits more immune activation of Th- 2 cytokines which inhibit Th-1 function, consequently influencing HIV disease progression when compared to other helminths.

Intensity of helminth infection (as defined by egg per gram of stool) had no significant relationship with CD4 T-cell count/ percentage in this study. This finding agreed with that reported by Akinbo et al ${ }^{14}$ among adult HIV infected patients. This may be explained by the findings of Bleul et $a^{24}$ who noted that during the asymptomatic stage of HIV infection, T-helper 1 cytokines predominates but with progressive loss of Th1 cells and advancement to AIDS, the HIV adapts to infecting Th2 cells with subsequent release of T-helper 2 cytokines such as IL- 4 and IL-10 which aids in the destruction of helminth and containment of the helminthiasis. Hence with immune-suppression, there is containment of helminthiasis in a co-infected patient.

Study by Hailmariam et a/ ${ }^{15}$ showed subjects with CD4 T-cell count less than $200 \mathrm{cell} / \mathrm{ml}$ had multiple (mixed) infections when compared to those with CD4 T-cell greater than $200 \mathrm{cell} / \mathrm{ml}$. In contrast, this study isolated only one species of helminth from infected subjects irrespective of their immunodeficiency stage. This may be explained by majority of the subjects in this study being on HAART.

\section{Conclusion}

In conclusion, there is a significant association between immunodeficiency state and prevalence of helminthiasis, routine de-worming of all HIV infected children is recommended.

Limitations of study: The subjects were not followed-up for at least 3 months to ascertain whether treatment of helminth infection improved immunologic stage of HIV infection. 


\section{References}

1. Global AIDS update 2016. Available at www.unaids. org/en/resources/documents/2016/Global-AIDSupdate-2016. Accessed on the 03/07/17

2. The 2012 National HIVIAIDS and Reproductive Health Survey-Plus. Available at www.thisdaylive.com/ articles/in-a-news. Accessed on the 23/04/14 .

3. National Guideline for Paediatric HIV and AIDS, Treatment and Care. Federal Ministry of Health of Nigeria. $2^{\text {nd }}$ edition. 2011; 9- 43.

4. Tindyebwa D, Kayita J, Musoke P, Eley B, Nduati R, Coovadia H. In: Tindyebwa D, Kayita J, Musoke P, Eley B, Nduati R, Tumwesigye N, Mwansambo C, MboriNgacha D, Kieffer MP, eds. Handbook on Paediatric AIDS in Africa. Africa network for the care of children affected by AIDS. $2^{\text {nd }}$ edition. Uganda: Family Health International. 2011; 3-26.

5. Basic HIV virology. Available at www.sinobiological. com/Basic-HIV-Human-Immunodeficiency. Accessed on the 23/04/14.

6. Weiss RA, Dalgleish AG, Loveday C, Pillay D. Human immunodeficiency viruses. In: Zuckerman AJ, Banatvala JE, Pattison JR, Griffiths PD, Schoub BD (eds). Principles and Practice of Clinical Virology. $5^{\text {th }}$ edition. Chichester: John Wiley and Sons Ltd. 2004: 721-57.

7. Cleghorn FR, Reitz MS, Popovic M, Gallo RC. Human Immunodeficiency Viruses. In: Mandell GL, Bennett JE, Dolin R (eds). Principles and Practice of Infectious Diseases. $6^{\text {th }}$ edition. Philadelphia: Churchill Livingstone, 2005; 2119-33.

8. Finchman JE, Markus MB, Adams VJ. Could control of soil transmitted helminthic infections influence the HIV/ AIDS pandemic? ActaTropica 2003;86:315-33. doi: 10.1016/S0001-706X(03)00063-9

9. MacDonald AS, Araujo MI, Pearce EJ. Immunology of parasitic helminth infections. Infect Immun 2002;70:427-33

10. Kalinkovich A, Weisman Z, Greenberg Z, Nahmias $J$, Eitan S, Stein M et al. Decreased CD4 and increased CD8 counts with cell activation is associated with chronic helminth infection. Clin Exp Immunol 1998;114:414-21.

11. Bentwich Z, Weisman Z, Moroz C, Bar-yehuda S, Kalinkovich A. Immune dysregulation in Ethiopian immigrants to Israel: relevance to helminth infection? Clin Exp Immunol 1996;103:239-43.

12. Borkow G, Bentwich Z. Chronic Immune Activation Associated with Chronic Helminthic and Human Immunodeficiency Virus Infections: Role of hyporesponsiveness and anergy. ClinMicrobiol Rev 2004;17:1012-30. doi: 10.1128/CMR.17.4.10121030.2004 .
13. Assefa S, Erko B, Medhin G, Assefa Z, Shimelis T. Intestinal parasitic infections in relation to HIVIAIDS status, diarrhea and CD4 T-cell count.BMC Infect Dis 2009;9:155. doi: 10.1186/1471-2334-9-155

14. Akinbo FO, Okika CE, Omeregie R. Prevalence of intestinal parasitic infection among HIV patients in Benin City, Nigeria. Libyan J Med 2010;5:5506. doi: 10.3402/ ijm.v5i0.55060.

15. Hailemariam G, Kassu A, Abebe G, Abate E, Damte D, Mekonnen $\mathrm{E}$ et al. Intestinal parasitic infections in HIV/ AIDS and HIV seronegative individuals in a Teaching Hospital, Ethiopia. Ethiopian J Infect Dis 2004;57:41-3.

16. Abaver DT, Nwobegahay JM, Goon DT, Iweriebar BC, Anye DN. Prevalence of intestinal parasitic infections among HIVIAIDS patients from two health institutions in Abuja, Nigeria. Afr Health Sci 2011;11 Suppl 1:S24-S7.

17. Wagbatsoma VA, Ogbaini E, Esene H, Ibadin K. HIV Sero-positivity and intestinal helminthiasis among children in a Tertiary health facility in Benin City, Nigeria. Niger. Med. Pract 2010;57:10-16.

18. Weather/ climate of Ebonyi state. Available at www. cometonigeria.com/search-by/ebonyi-state. Accessed on the $27 / 04 / 14$.

19. Federal Republic of Nigeria. 2006 population and housing census of Nigeria. Federal Republic of Nigeria official gazette. Lagos 2007; 94.

20. Montresser A, Crompton DWT, Hall A, Bundy DAP, Savioli L. Guidelines for the eradication of soil transmitted helminths and schistosomiasis at community level. Schistosomiasis and Intestinal Parasite Unit, division of control of Tropical Diseases. WHO/CTC/SIP/98.1998

21. Oguanya FC, Okogun GRA, Akhile AO, Eloka CCV, Okoro CJ, Okpe AL. Prevalence of Soil-Transmitted Helminth infections among public primary school pupils in Ekpoma, Edo State, Nigeria. I J Comm Res 2012;1:30-4. Available at http://www.anrescentpub. com. Accessed on 22/06/16

22. Shehu MM, Kabiru A, Abubakar U, Mohammed K. Prevalence of intestinal helminth infection among school children in relation to occupation of parents and toilet facilities in Manu L.G.A, Zamfara State. J Bio Agric Healthcare 2013;3:87-90.

23. Mkhize-kwitshana ZL, Taylor M, Jooste P, Musawenkosi LH, Walzl G, Walzl M. The influence of different helminthic infection phenotypes on immune responses against HIV in co-infected adults in South Africa. BMC Infect Dis 2011;11:273.doi: 10.1186/1471-2334-11-273

24. Bleul CC, Wu L, Moxie JA, Springer TA, Mackay CR. The HIV co-receptors CXCR4 and CCR5 are differentially expressed and regulated on human T-lymphocytes. Proc. NatIAcadSci USA 1997;94:192530. 